\section{European Community plans to sequence yeast genome}

Munich

WHILE the United States National Institutes of Health are attracting the world's attention with their grand plans to map and sequence the human genome, the European Community (EC) has quietly begun a smaller but still significant project: to sequence the genome of yeast.

A two-year pilot project to sequence one yeast chromosome was passed in mid-February in Brussels by the advisory committee of the EC's Biotechnology Action Programme. The project will provide 2 million $\mathrm{ECU}(1 \mathrm{ECU}=\$ 1.24$ at current rates) to between 20 and 40 laboratories. Formal approval from the EC is expected soon.

The project could be expanded in 1991 under the BRIDGE programme to sequence the entire yeast genome, in conjunction with Japan and the United States. Project leader Andre Goffeau said the EC might make as much as 10-20 million ECU available for the sequencing of yeast and other 'industrial microbes' under the auspices of BRIDGE.

Fifty yeast laboratories from almost every EC country-but especially from France, West Germany and Belgiumhave expressed an interest in the pilot project. Each laboratory would receive 10-15 kilobases (kb) per year to sequence using methods of their own choosing. In addition, each laboratory would check

the results of one other laboratory. genome consists of 3 million $\mathrm{kb}$. West Germany. six EC countries. about interpreting sequence data."
The chromosome to be sequenced, chromosome 3 , was chosen because of its small size as well as because of access to an organized library of overlapping clones thanks to Maynard Olson of Washington University in St Louis and others in the United States. Chromosome 3 contains about $360 \mathrm{~kb}$ of DNA; the entire yeast genome contains about $15,000 \mathrm{~kb}$. By contrast, the human

A centre to coordinate the sequence data is essential, says Goffeau. A likely candidate is the Martinsried Institute for Protein Sequence data near Munich,

Goffeau is optimistic that the yeast sequencing project will attract widespread industrial support, which may be essential for the project's well-being. A preliminary study revealed broad interest from breweries, pharmaceutical companies and biotechnology firms in five or

Goffeau sees the yeast project as a stepping stone to the sequencing of the human genome, which will take much longer because of the lack of an organized library. By the time systematic sequencing of the human genome begins, "we will have learned a lot from yeast

Steven Dickman

\section{UK wind power project}

\section{London}

Britain's Department of Energy and Central Electricity Generating Board have announced a joint $\$ \mathbf{3 0}$ million pilot programme to produce electricity from three experimental 'wind parks' and a single offshore wind turbine. Each park, whose sites have yet to be chosen, will have 25 wind turbines, generating suffcient electricity for the needs of 15,000 people. According to Lord Marshall, the board's chairman, a typical wind park could consist of $30-\mathrm{m}$-high turbines of either vertical or horizontal axis design, with blades of about 30-m diameter. Each machine would have an output of 300-500 kW and a single park would occupy 3-4 square kilometres. The intention is that the wind parks should be built within the next four years, with a $25 \mathrm{MW}$ output by 1993. The offshore turbine is expected to have a horizontal axis mounted on a steel tripod some $8 \mathrm{~km}$ off the East Anglian coast.

When the government announced its plans for the privatization of the electricity supply industry last month, a commit- ment was given for the new distribution companies to place contracts for a minimum (as yet unquantified) proportion of non-fossil-derived electricity, mainly as a way to guarantee the continuing expansion of the nuclear power programme, but also to encourage a greater diversity of sources of renewable energy, such as wind power.

Launching the wind park programme on 23 March, energy minister Michael Spicer estimated that upon the successful development of the technology, wind energy could contribute up to 20 per cent of Britain's electricity. He conceded, however, that society's attitude to the prospect of large numbers of wind turbines spread over vast tracts of the countryside would determine the eventual feasibility of the scheme. It has been calculated that on the basis of present technology, it could take a hundred square miles of windmills to produce one per cent of the nation's electricity. "It is essential, therefore, that we consider very carefully the environmental implications of pursuing this technology", said the minister. Simon Hadlington

\section{Harvard tries teaching from afar \\ Boston}

A HARVARD professor last week taught a method for solving a linear algebra problem not only to her students in the United States, but at the same time to a faculty panel in Beijing, China via an interactive computer and telephone connection. The so-called simultaneous classroom was a preview of a computer communication system to be used for a five-week course between Harvard and Beijing Normal University on expert systems that will begin next month.

The system employs a communication link that allows voice and data messages to be sent over a single telephone line simultaneously. The teacher, the US students and the Chinese delegation each use workstations with IBM-compatible computers, speakerphones for voice communication, and electronic tablets so equations can be written by hand.

The preliminary two-hour segment was, for the most part, a demonstration of the US style of teaching mathematics, where interaction between students and faculty is more frequent than in the Chinese system. But the first session included a fair amount of ceremony as well. While still video images depicting each campus flickered on the computer screens, the two university presidents introduced their respective institutions with short, if lofty, presentations.

The classes on expert systems will use the same system to link Harvard computer scientist Henry Leitner with approximately twenty Chinese graduate students in computer science, using educational software developed by a firm called Cambridge Teleteaching Group.

The Harvard programme comes hard on the heels of an arrangement China has made with Boston University Medical School to use a similar system to teach a five-week series on medical topics. Both of these programmes were initiated by Chinese officials who contacted the US State Department hoping to strengthen educational and informational ties between the two countries. The teleteaching programmes received a small grant from the US State Department, with the telephone time donated by AT\&T.

A teleteaching experiment between the United States and the Soviet Union was launched last month at Tufts University using an interactive video link. This course on nuclear history pairs Professor Martin Sherwin and class with a Soviet group headed by Yevgeny Velikov, vice president of the Soviet Academy of Sciences. 